Lukáš Hadamčík, Ph.D.

Faculty of Law, Masaryk University, Brno, Czech Republic
ПРЕГЛЕДНИ НАУЧНИ РАД

doi: $10.5937 /$ zrpfn0-23230

UDK: 347.453(437.1/.2)

Рад примљен: 18.09.2019.

Рад прихваћен: 19.11.2019.

\title{
LESSOR'S NOTICE OF TERMINATION OF RESIDENTIAL LEASE IN CZECH LAW
}

\begin{abstract}
Czech private law underwent a major change in 2014, when the new Civil Code came into force. The changes also influenced the regulation of residential leasing. Renting a flat or house is a very common means of satisfying the need for housing in the Czech Republic. In 2011, one quarter of all flats in the Czech Republic were rented. A lessee is considered to be the weaker party in a lease relationship. For this reason, there is strong legal regulation. One way to protect lessees is to limit the lessor's right to give notice. The aim of this contribution is to present Czech regulation on the termination of residential leases, mainly the circumstances and conditions under which the lessor has the right to give notice.
\end{abstract}

Key words: Residential lease, notice of termination, civil law, rent, lessee, lessor.

\section{Introduction}

The legal regulation of residential leases in the Czech Republic started evolving in the early 1990s. Until then, the housing policy was entirely controlled by the state. Residential lease did not exist in the legal code. Instead, the institution of personal use of apartments was applied. It was only after the fall of the communist regime that a number of traditional private law institutions, including lease law, were reintroduced into civil law. A substantial part of the housing fund was restituted and privatised. The protection of lessees was originally embodied in the amended Civil Code of 1964, Act No. 40/1964 Coll., Civil Code, as amended (hereinafter referred to as the CivC 1964). In 2014, the new Civil Code, Act No. 89/2012 Coll., came into effect (hereinafter referred to as the "CC"). The regulation of residential lease is found under Section 2235 to 2301 of this act.

\footnotetext{
*lukas.hadamcik@law.muni.cz
} 
In the Czech Republic, there is no special regulation on social housing, although the need for this legislation has been discussed for years. Hence, the present situation is such that the legal regulation of residential lease does not distinguish whether the lessor of the apartment is a public entity (e.g. municipality) or a private entity. The same strict rules apply irrespectively to all apartments which are leased for the purpose of satisfying the lessee's housing need.

One of the ways in which the lessee's position is traditionally protected is the restriction of the lessor's right to give notice of the lease. The aim of this contribution is to introduce the individual reasons for notice of termination, on the basis of which the lessor is entitled to terminate the lease.

\section{Basic reference points}

First and foremost, it must be noted that the regulation of residential lease in Czech law is relatively cogent. It is not possible to diverge from legal provisions by agreement, should such agreement result in the curtailment of the lessee's rights (compare Section 2235(1), CC).

Czech law enables the agreement on a lease for both a definite or indefinite term. However, no matter if the lease was agreed for a definite or indefinite term, under no circumstances is the lessor authorised to give notice of termination without relevant reasons.

This situation seemingly contradicts the concept of lease as a relative legal relationship, where the substance of relative legal rights is their limited duration in time. The institute of notice as a unilateral legal act which leads to the termination of the obligation prevents the existence of temporally unlimited relative legal relationships. In the case of the lessor, however, the lease cannot be unilaterally terminated if a relevant reason for notice does not exist. This limitation is relevant under the circumstance that the residential lease serves to satisfy the basic human need of the lessee, that being the need for housing. Nevertheless, the restrictions are fairly significant. During the drafting of the civil code, the option of notice without giving a reason for termination on the part of the lessor was also considered, whereas a relatively long (two-year) notice period should have been introduced simultaneously to protect the lessee in this case. However, this provision was not incorporated into the effective civil code.

The current legislation thus leads to a practice in which lease agreements between private entities for an indefinite term are concluded only minimally. For, if the legal code allows the lessor to conclude the lease for a definite term (e.g. one year) and to extend this lease without limitation, then it would be difficult to imagine that the lessor would be interested in voluntarily giving up the option 
of considering at least once per year whether they are interested in continuing the legal relationship or whether they would prefer to use the apartment for a different purpose or lease it to another lessee.

It should be noted that no lower limit is stipulated for the period for which the lease of the apartment may be agreed. For example, Spanish legislation foresees minimally three years, whereas a shorter agreed term of lease shall be automatically extended until the said three years, which may be prevented without giving a reason only by the lessee; on the contrary, the lessor may do so only for the reasons stipulated by law [Art. 9 of Act No. 29/1994 of 24 November, on municipal leases (de Arrendamientos Urbanos), as amended]. Czech law does not stipulate any such limitations, which in practice results in the possibility of encountering a lease deliberately concluded for an inadequately short term (e.g. three months). However, if the purpose of such agreed lease terms is to evade the provision on notice, it is an obvious evasion of the law, which means that the given provision shall be disregarded pursuant to Section 2235(1), CC. In this case, the lease shall be considered agreed for an indefinite term (compare Section 2204(1), CC).

\section{Categorisation of notice reasons}

The notice reasons may be sorted according to several criteria: firstly, the length of the notice period (three months or without a notice period); secondly, whether the reason is on the part of the lessee or lessor, or whether the notice is given for reasons of public interest (Bajura: 42). In Section 2288 CC, categorisation was chosen depending on the relevance of the notice reason in relation to whether the lease is for a definite or indefinite term. The author adheres to this categorisation. However, we have to prepend sanctioning notice reasons, which by their nature fall into the category of notice reasons relevant to leases regardless of the agreed lease term, due to the fact that this is the most problematic category in terms of interpretation.

\section{Sanctioning notice reasons}

The sanctioning notice reasons are regulated in the provisions of Section 2291 CC, and Section 2288(1)(a) and (b) CC. The substance of the sanctioning notice reasons is that, in this case, the notice is a reaction to a breach of obligations by the lessee. For this purpose, the Civil Code implements categories of breach of obligations by the lessee according to their intensity:

- particularly serious breach (Section $2291 \mathrm{CC}$ ),

- material breach (Section 2288 CC), 
- $\quad$ serious breach (Section 2269(2) and Section 2272(2) CC).

- minor breach.

The intensity of the breach of obligations affects the existence of the lessor's right to give the lessee notice. A minor breach of obligations cannot lead to a notice of termination of the lease. Likewise, a serious breach of obligation in itself does not establish the right to give the lessee notice, but depending on the reason report in the case of a repeated serious breach, the breach may gain in intensity to become a material or particularly serious breach (Eliáš, Zuklínová, Gaňo, 2012: 863). A material breach of obligation is a reason for notice with a three-month notice period pursuant to Section 2288(1) CC. A particularly serious breach of obligation is a reason for notice without a notice period pursuant to Section 2291 CC.

It may seem that the provision of Section 2291 CC is stricter towards the lessee as compared to Section 2288 CC. This conclusion may be inferred from the fact that it grants the lessor the right to give the lessee notice without a notice period. This conclusion is also suggested by the fact that this includes sanctioning notice reasons with a higher degree intensity of obligation breach. However, upon detailed examination of this provision, we can draw the conclusion that it is a much more benevolent provision in relation to the lessee. Despite the fact that the lessor has the right to terminate the lease without a notice period, the lessor's procedure pursuant to this does not lead to the faster termination of the lease than under Section 2288 CC. According to the third clause of Section 2291 CC, the lessor is obliged to invite the lessee to eliminate the deficient conduct or the unlawful situation within a reasonable period before delivering the notice. Therefore, the notice period in this provision is merely replaced with a reasonable period, which must be granted to the lessee to eliminate the deficient conduct or unlawful situation. Only if the lessee does not respond according to the request within the given period can the lessor give them notice, in which the lessor must clearly specify where it perceives the particularly serious breach of the lessee's obligation. Pursuant to Section 2291(1) CC, the lessee has one month from termination of the lease to hand over the apartment.

It is the lessor's obligation to make this request which leads to the conclusion that the provision protects the lessee's rights to a greater extent than Section 2288 CC because, according to the latter provision, the lessor need not make any such request. If the lessee reacts to the request and rectifies the deficient conduct or the unlawful situation, then it is necessary to draw the conclusion that the lessor does not have the right to give notice pursuant to Section 2291 CC. The opposite conclusion would suggest that the requirement for the request would be a mere redundant formality. 
Given that the particularly serious breach of obligations is more intensive than a material breach, the lessor has the right to choose whether it shall proceed pursuant to Section 2288 CC, or Section 2291 CC, in the case of such breach. However, if they choose the procedure pursuant to Section 2291 CC, and make the request under clause (3), they are no longer authorised to give notice based on this fact even pursuant to Section 2288 CC; otherwise, the request would again be a mere redundant formality (Brzobohatá, 2017). ${ }^{1}$ Likewise, the Supreme Court has drawn the conclusion that the notice reason is void in this case. ${ }^{2}$ In other words, if the lessee breached the obligation in a particularly serious manner and the lessor is not interested in the continuation of the legal relationship, it should not request any thing from the lessee and should proceed immediately pursuant to Section $2288 \mathrm{CC}$, that is, to give the lessee notice with a three-month notice period. If the lessor proceeds pursuant to Section $2291 \mathrm{CC}$, he exposes himself to the risk that the lessee shall rectify the unlawful situation based on the request, and the lessor shall thus be unable to terminate the problematic legal relationship.

\subsection{Particularly serious breach of obligations}

The provision of Section 2291(2) CC contains a demonstrative list of individual breaches of obligations in a particularly serious manner:

- the lessee fails to pay rent and costs for service for a period of at least three months,

- the lessee damages the apartment or house in a severe and irreparable manner,

- the lessee causes other serious damage or problems to the lessor or persons living in the building,

- the lessee uses the apartment in a different manner or for other purposes than those agreed.

\subsubsection{Non-payment of rent and costs for services}

The non-payment of fees related to living can apparently be considered the most common reason leading to notice of termination of the lease. Hence, it is evident that this notice reason was included in the prior legislation. However, the legal formulation of the notice reason changed even during the effectiveness of the previous civil code, with a corresponding change in case law. Pursuant to Section 711(1)(d) CivC 1964, as amended until 30 March 2006, the lessee

1 Contrarily (Selucká, Hadamčík 2015: 248)

2 Rozsudek Nejvyššího soudu ze dne (Judgment of the Supreme Court of) 18. 1. 2017, sp. zn. 26 Cdo 4249/2016. 
seriously breached their obligation from the lease if he/she "did not pay rent or fees for performance related to use of the apartment for more than three months." From the said provision, case law inferred that the value of the debt was not relevant, but rather the period for which the lessee did not pay these debts. ${ }^{3}$ Hence, in addition to a situation when no amount was paid on the grounds of rent, the non-payment of rent pursuant to this provision also referred to situations when the lessee did not pay the rent in full. ${ }^{4}$ Following the amendment implemented under Act No. 107/2006 Coll., the notice reason was changed so that the lessee seriously breached the obligation if he/she "did not pay rent and fees for performance provided with use of the apartment in the amount corresponding to three times the monthly rent and fees for performance provided with use of the apartment." Pursuant to this version, the period for which the lessee did not pay rent was no longer decisive, but rather the value of the debt. The conjunction was also changed. While the aforementioned version contained the conjunction "or", after the amendment it contained the conduction "and". From this as well, it must be inferred that the non-payment of rent in full no longer suffices, but rather that the arrear must include the amount for services and the amount for rent, whereas the value of the arrear is simultaneously defined as a multiple of the monthly agreed amount for rent and services (Fiala, Kindl, 2009:1379).

If we compare the current version with the foregoing, then the current regulation again contains the phrase "for at least three months", from which it may be inferred that the legislators again returned to the diction effective before 30 March 2006 and, therefore, that the period of the lessee's default rather than the value of the debt is decisive. On the other hand, the conjunction "and" has remained intact, from which on the contrary it may be inferred that it should still refer to the sum of payments, and not only partial non-payment. Hence, the current interpretation is not definite. Bajura deduces that it is necessary to apply the case law pertaining to the version before its amendment (Bajura, 2014: 42). On the contrary, Selucká notes that the breach of obligations must fulfil the general clause, meaning a "particularly serious breach of obligation". For this reason, the debt must have the attributes of a qualified debt, meaning that the given provision must be interpreted to mean that it is an amount equal to the sum of payments for rent and for costs of services for three months (Hulmák, 2014: 469). The author of this paper is inclined towards the last stated conclusion. For, the given provision cannot be interpreted in isolation but in the context of the

3 Rozsudek Nejvyššího soudu ze dne 20. 5. 2008, sp. zn. 26 Cdo 731/2008.

4 Usnesení Nejvyššího soudu ze dne 6. 2. 2003, sp. zn. 26 Cdo 585/2002, uveřejněné pod C 1693 ve svazku 23 Souboru rozhodnutí Nejvyššího soudu (Order of the Supreme Court of 6. 2. 2003, sp. zn. 26 Cdo 585/2002, published under C 1693 in Volume 23 of the Supreme Court Decision File.) 
legislation as a whole. It is essential to realise that, in the previous regulation, this breach under the effectiveness of both versions led to notice with a three-month notice period. The conclusions of case law before the amendment correspond to this, as it was clearly the intention to also sanction lessees who do not pay their debts even in part. This would not be possible under any provision other than that cited above. However, according to the current legislation, the failure to make payments in full may take on the intensity of a material breach. The lessor is then authorised to give the lessee notice pursuant to Section 2288(1)(a) CC. For this reason, it is no longer possible to simply accept the conclusions of case law pertaining to the solving of this issue pursuant to the previous legislation.

There was also an evolutionary shift in case law concerning the means by which the lessor must factually define the notice reason in the notice. Until 30 June 2006, case law did not require the lessor to sate the specific months for which the rent was not paid. However, this was due to the fact that notice could only be given with permission from the court, meaning that the lessor was obliged to prove the fulfilment of the notice reasons in factual terms in the proceedings. ${ }^{5}$ Given the fact that from 31 March 2006, it was a notice reason without permission from the court, case law required that the lessor precisely specify when and how much the lessee failed to pay on rent or service fees to ensure adequate certainty. ${ }^{6}$ In my opinion, there is no relevant reason why this conclusion should not apply likewise to the current legislation. ${ }^{7}$

\subsubsection{Damage to the apartment or house in a severe and irreparable manner}

This notice reason works with other vague terms such as "serious or irreparable manner". Hence, the question arises based on what criteria the reaching of the given intensity can be assessed. Bajura refers to damage higher than that which suffices to establish criminal liability (meaning CZK 5,000) (Bajura, 2014: 49). On the contrary, Selucká opts for the viewpoint of the preceding notice reason, meaning three times the monthly rent and costs for services (Hulmák, 2014: 471). The latter opinion seems to be the more appropriate. The previous civil code already specified the lessee's default merely as an example of a material breach of the lessee's obligations which constituted a notice reason. In the case of a breach of the lessee's obligations in other ways, case law inferred that when assessing the intensity of the breach, it is necessary to consider whether this other breach in its significance is at least as serious as the non-payment of rent (service fees), which the law expressly identifies as a "material" breach. ${ }^{8}$ In my

5 Rozsudek Nejvyššího soudu ze dne 8. 6. 1999, sp. zn. 26 Cdo 2259/98.

6 Rozsudek Nejvyššího soudu ze dne 25. 11. 2009, sp. zn. 26 Cdo 1109/2009.

7 Contrarily (Hulmák, 2014: 471).

8 Rozsudek Nejvyššího soudu ze dne 22. 4. 2004, sp. zn. 26 Cdo 85/2004. 
opinion, the same conclusion may be applied to the current legislation, meaning that the intensity may be assessed according to the preceding notice reason.

4.1.3. Causing serious damage or problems to the lessor or persons living in the building

The notice reason is directed firstly at the relationship between the lessor and lessee, which should be free of conflict, meaning that the lessee should not damage the apartment and should not cause serious damages or other problems to the lessor. The notice reason is also directed at peaceful cohabitation in the building. In my view, the previous notice reasons pursuant to Section 711(2) (a) CivC 1964, meaning a material breach of good morals in the building, can be included herein. Case law provides the following incomplete list: bothering of lessees beyond the reasonable limits by various immission (e.g. excessive noise, odour, insects, dirt, inadequate breeding of animals), or verbal or even physical abuse of the other lessees or the lessor, whereas the intensity can be assessed based on the severity of the consequence of the lessee's conduct and the extent of its duration or recurrence. ${ }^{9}$

4.1.4. Unauthorised use of the apartment in a different manner or for other purposes than those agreed

If the purpose of lease is not the permanent housing of the lessee or their family members in the meaning of Section 2235(1) CC, then it is not a residential lease. Hence, the said notice reason reacts to situations when the lessee does not use the apartment for the aforementioned agreed purpose, but for a different purpose. Naturally, it cannot be a different purpose which is related to the lessee's housing and which is expressly permitted by legislation, e.g. working or operating a business in the apartment (Section 2255(2) CC) or keeping a pet (Section 2258 CC).

It must be noted that the law mentions the foregoing situations as an incomplete list only. Therefore, it will always be necessary to assess the specific situation to determine whether the intensity of the breach of other obligations reaches the degree of a particularly serious breach. Furthermore, it must be such a breach which by its nature is reparable, so as to allow for the request pursuant to Section 2291(3) CC. If it is an irreparable breach, be it of particularly serious intensity, the lessor may proceed only pursuant to Section 2288(1)(a) CC, and give the lessee notice with a three-month notice period. ${ }^{10}$

9 Rozsudek Nejvyššího soudu ze dne 24.11. 2005, sp. zn. 26 Cdo 1865/2004, uveřejněný ve Sbírce soudních rozhodnutí a stanovisek pod č. 51/06. (Judgment of the Supreme Court sp.zn. 26 Cdo 1865/2004, published in the Collection of Judgments and Opinions under No. 51/06.)

10 Rozsudek Nejvyššího soudu ze dne 18. 1. 2017, sp. zn. 26 Cdo 4249/2016. 


\subsection{Material breach of obligations}

A material breach of obligation constitutes a notice reasons pursuant to Section 2288(1) CC, and is thus a reason for notice with a three-month notice period. As concerns a material breach of obligations, the Civil Code does not contain any similar demonstrative list. It expressly identifies the situation where the lessee unrightfully arranges a sublease as a material breach of obligations (Section 2276 CC). Incidentally, this applied also under the previous legislation (Section 719(1) CivC 1964).

On the contrary, compared to the previous legislation (Section 689(2) CivC 1964), it is no longer a material breach of the lessee's obligations if the lessee does not inform the lessor about an increase in the number of people living in the apartment pursuant to Section 2272(1) CC. For, the law stipulates the intensity of this breach as serious. Likewise, it identifies the breach of the reporting obligation pursuant to Section 2269(2) CC as serious.

The intensity of a material breach of obligations will have to be assessed according to the specific circumstances of the given case, whereas it may be a breach of any obligation from the lease. It is irrelevant whether the obligation arises from the law or from the agreement. However, if it is a contractual obligation, it must not be contrary to Section 2239 CC, meaning that it cannot be an obligation which is obviously unreasonable under the circumstances.

\subsection{Conviction of an intentional criminal offence}

The last sanctioning notice reasons for notice with a three-month notice period is regulated in Section 2288(1)(b) CC: "if the lessee is convicted of an intentional criminal offence against the lessor or a member of their household or a person living in the building where the lessee's apartment is located, or against the property of another which is located in the building." It may seem strange that the legislators included this notice reasons among the reasons pursuant to $2288 \mathrm{CC}$, with a three-month notice period, when they simultaneously defined the option of notice without a notice period, because the commission of a criminal offence may be considered the most serious breach of the lessee's obligations. However, it is necessary to realise what the reason for notice is, in this case and subsequently, to connect this conclusion with the meaning of 2291 CC, explained above.

The notice reason in this case is not the act committed by the lessee, for which they were convicted, but rather the verdict under which they were convicted. Before this verdict, the act which the lessee committed will have fulfilled some of the notice reasons pursuant to Section 2291 or Section 2288(1)(a) or (d) $\mathrm{CC}$, and the lessor may thus already give the lessee notice pursuant to these provisions. In potential civil proceedings commenced by the lessee pursuant 
to Section 2290 CC, the lessor shall bear the burden of proof that the reason for notice was fulfilled in factual terms in this case. On the contrary, in the case of notice pursuant to Section 2288(1)(b) CC, the court is bound by the decision that a criminal offence has been committed.

The inclusion of this notice reason under Section 2288 CC corresponds to the fact that the lessee cannot eliminate the effective verdict based on their own will. For this reason, procedure pursuant to Section 2291 CC is not possible. ${ }^{11}$ In the case of a criminal offence whose consequence can be rectified, whereas the lessor proceeds pursuant to Section 2291(3) CC even before the decision of the criminal court (meaning that they make a request to which the lessee reacts and rectifies their misconduct), it is questionable whether the lessor is still entitled to the notice reason pursuant to Section 2288(1)(b) CC, after the effective conviction of the lessee. It has already been stated above that in the case of rectification, the lessor is not entitled to the notice reason pursuant to Section 2288(1)(a) CC. In my opinion, however, the situation is different in this case. While the conclusion on preclusion of the notice under letter (a) resulted from the fact that it is the same act, in the case of the notice under letter (b) the reason for notice is an effective verdict. The circumstance that it was issued based on the same act is secondary, in my opinion, precisely because it is a specially regulated notice reason. Hence, I support the opinion that the lessor is entitled to the notice reason even in this case.

\section{Other notice reasons from lease for an definite and indefinite term}

In addition to the aforementioned sanctioning notice reasons, the lessor may give the lessee notice from the lease for a definite or indefinite term also with a threemonth notice period pursuant to Section 2288(1)(c) and (d) CC. Under letter (c), the lessor is authorised to give notice: "if the apartment is to be vacated because for reasons of public interest, it is necessary to handle the apartment or building in which it is located so that it can no longer be used at all." This notice reason was also included (with certain less important differences) in the previous legislation, but it was a notice reason with permission from the court [Section 711a(1)(b) CivC 1964]. Pursuant to the established practice of the Supreme Court, the lessor has the right to give the lessee notice based on this reason only if the decisive claim contained in the notice is substantiated by the respective administrative act of the building authority (or other entity specified by the building code) pursuant to building regulations. ${ }^{12}$ Case law simultaneously came to the conclusion that the term "public interest" makes this provision a legal norm with a relatively

11 Rozsudek Nejvyššího soudu ze dne 18. 1. 2017, sp. zn. 26 Cdo 4249/2016.

12 Rozsudek Nejvyššího soudu ze dne 31. 8. 1998, sp. zn. 3 Cdon 7/96, uveřejněný v Soudní judikatuře z oblasti občanského, obchodního a pracovního práva č. 21/98 na s. 492. (Judgment 
indefinite hypothesis. Hence, it is up to the court to define the circumstances in which it perceives the fulfilment or non-fulfilment of the condition of existence of public interest in the judged case. ${ }^{13}$ Because the current Civil Code does not recognise notice with court permission, the court's consideration regarding the existence of public interest will thus be applicable only in the case of proceedings commenced pursuant to Section 2290 CC. An analogy of this notice reason is also contained in Section 7(2) of Act No. 184/2006 Coll., on the revocation or restriction of ownership of land or buildings (Expropriation Act), as amended: "Upon expropriation, the lessor may give notice from the lease of the apartment, commercial premises, building or land also if their further use prevents the purpose of expropriation, in addition to the reasons specified by special legal regulation."

The provision of Section 2288(1)(d) CC, makes the list of notice reasons open, because pursuant to this provision the lessor has the right to give notice from the lease: "if there is another similarly serious reason for terminating the lease." According to the original reason report, however, this clause must be interpreted restrictively (Eliáš, Zuklínová, Gaňo, 2012: 868).

The lessor is entitled to a special notice reason pursuant to Section 2283 CC, in the case of the lessee's death and passing of the lease to their heir pursuant to Section 2282 CC.

\section{Notice reasons for lease for an indefinite term}

If the lease was agreed for an indefinite term, the lessor has two additional notice reasons beyond the framework of the notice reasons specified above. Pursuant to Section 2288(2)(a) CC, the lessor may terminate the lease in the three-month notice period if "the apartment is to be used by the lessor, their spouse, who intends to leave the family household, and a petition for divorce of the marriage has been filed or the marriage has already been divorced." In specialised literature, there was a dispute over whether this notice reason may be applied only in the case of divorce of marriage (meaning whether the part of the sentence after the conjunction "and" also applies to the lessor), ${ }^{14}$ or whether the lessor may give notice from the lease if the condition that it is to be used by the lessor without further ado is fulfilled (the part of the sentence after the conjunction "and" applies only to the lessor's spouse) (Bajura, 2014: 73). The Supreme Court carried

of the Supreme Court of 31 August 1998, file no. 3 Cdon 7/96, published in the Court's caselaw on civil, commercial and labor law n. 21/98, p.492)

13 Rozsudek Nejvyššího soudu ze dne 8. 4. 2009, sp. zn. 26 Cdo 1642/2008.

14 This opinion can be found apparent for the first time in the work by Bezouška, Petr. Housing policy all around. (Eliáš, 2014:248). This opinion may also be implicitly deduced from commentary literature (Hulmák: 2014: 460). A more detailed argumentation of this opinion is offered by Křček (Křeček, 2016:122-123). 
out the grammatical, historical, theological and systematic interpretation of the given provision, coming to the following conclusion: "If the apartment, the lease of which is being terminated, is to be used by the lessor, the notice reason pursuant to Section 2288(2)(a), CC, is fulfilled without further ado; only if the apartment is to be used by the lessor's spouse, who intends to leave the family household, must the lessor prove that a petition to divorce the marriage has been filed, or that the marriage has already been divorced." 15

Pursuant to Section 2288(2)(b) CC, the lessor is also authorised to give notice form the lease with a three-month notice period if: "the lessor needs the apartment for their relative or their spouse's relative in a direct line or in collateral line in the second degree."

Hence, this is an analogy of the earlier notice reason pursuant to Section 711a(1) (a) CivC 1964. In relation to the previous regulation, the Supreme Court already deduced that the given provision does not require the lessor to be a person who does not have their own apartment. The lessor's need for housing from the perspective of this provision is given even in the cases when the lessor has their own apartment, but wants to improve their housing conditions. ${ }^{16}$ The said change must therefore be interpreted in the meaning of the said case law, which is not that any use by the lessor is sufficient (e.g. use of the apartment as storage or for the lessor's business), but only use of the apartment for permanent housing of the lessor. The opposite interpretation would mean that the lessor would be authorised to give notice from the lease at any time, essentially without a notice reason. The owner of the apartment (or person with other rights to the apartment), as a rational manager, would not leave apartment unused. Given the foregoing, the earlier conclusion of case law that a lessor who is a legal entity cannot give notice from the lease under this provision will apparently remain intact. ${ }^{17}$

In my opinion, the conclusions of case law pertaining to assessing the validity of the notice pursuant to this provision in terms of its compliance with good morals are likewise still applicable. Hence, in the case of notice pursuant to Section 2288(2) CC, the lessor must also take into account the potential advanced age of the lessee, how long they have lived in the apartment, the consequences their moving to another apartment could have for their health and, in the case of the notice reason under letter (b), urgency of the need for housing of the person in whose favour the apartment lease is being terminated in relation to these facts. ${ }^{18}$

15 Rozsudek Nejvyššího soudu ze dne 22. 11. 2016, sp. zn. 26 Cdo 1454/2016.

16 Rozsudek Nejvyššího soudu ze dne 22.12. 1998, sp. zn. 2 Cdon 1246/97.

17 Rozsudek Nejvyššího soudu ze dne 26. 3. 1998, sp. zn. 3 Cdon 1/96, uveřejněný v Soudní judikatuře z oblasti občanského, obchodního a pracovního práva č. 21/98 na s. 489.

18 Rozsudek Nejvyššího soudu ze dne 16. 3. 2004, sp. zn. 26 Cdo 1619/2003. 
In order for the notice pursuant to this provision to be definite, the lessor must expressly state in the notice the person in whose favour the lease is being terminated pursuant to the cited provision. ${ }^{19}$

Pursuant to Section 2289 CC, the lessor is given a deadline of one month to use the apartment for the purpose specified as the notice reason. This deadline does not run for the period needed to modify the apartment, if modifications were commenced maximally within two weeks after vacating the apartment and are duly progressed. If the lessor does not do so, he is obliged to lease the apartment to the lessee again or compensate their damages. The conjunction "or" is used here in an aggregative meaning so that the repeated lease of the apartment to the lessee does not preclude the lessor's obligation to compensate the lessee's damage. The given provision should thus protect the lessee from the misuse of the given notice reasons. However, it must be noted that the practical control of whether the lessor fulfilled the said conditions will surely be difficult, because the lessee has no right to conduct such control.

\section{Conclusion}

The restriction of notice reasons based on which the lessor is authorised to terminate the lease is traditionally one of the means of protecting the lessee. The Czech civil code does not allow the lessor to give notice from the residential lease without giving one of the reasons specified by law.

Legislation categorises the notice reasons according to whether they pertain only to a lease agreed for an indefinite term, or also to a lease for a definite term. Sanctioning notice reasons may be defined as a special category.

In terms of sanctioning notice reasons, the civil code introduced the differentiation of the breach of the lessee's obligations into particularly serious breach, material breach, serious breach and minor breach. It will be the task of judicial practice to define these indefinite legal terms. A particularly serious breach of obligation may lead to notice without a notice period. Paradoxically, however, the regulation of notice without a notice period may be seen to strengthen the protection of the lessee's rights. For, before giving such notice, the lessor must give the lessee an opportunity to rectify the deficient conduct or unlawful situation within a reasonable period. Only if the lessee fails to do so is the lessor authorised to give notice from the lease without a notice period. The lessee then has one month to hand over the apartment to the lessor. Hence, the given procedure does not lead to the faster termination of the obligation.

19 Rozsudek Nejvyššího soudu ze dne 22.12. 1998, sp. zn. 3 Cdon 1477/96, uveřejněný v Soudní judikatuře z oblasti občanského, obchodního a pracovního práva č. 4/2000 na s. 130. 


\section{References}

Bajura, J (2014). Výpověd' z nájmu bytu a jiné způsoby skončení nájmu bytu, přechod nájmu bytu podle nového občanského zákoníku. Olomouc: Anag, spol. s r.o.

Brzobohatá, P. (2017) Aktuální otázky nájmu bytu a prostor sloužících k podnikání. Training organised by the Justice Academy in Kroměříž on 18 - 20 January 2017.

Eliáš, K., Zuklínová, M., Gaňo, J., et al. (2012). Nový občanský zákoník s aktualizovanou důvodovou zprávou a rejstríkem. Ostrava: Sagit, a.s.

Eliáš, K., et al. (2014) Občanské právo pro každého: pohledem (nejen) tvůrců nového občanského zákoníku. Praha: Wolters Kluwer ČR

Selucká, M., Hadamčík, L. (2015). Nájem bytu a domu po rekodifikaci soukromého práva. Praha: Wolters Kluwer ČR, a. $\mathrm{S}$

Fiala, J., Kindl, M., et al. (2009). Občanský zákoník, Komentář. II. díl. 2. vyd. Praha: Wolters Kluwer ČR, a. s.

Hulmák, M. et al. (2014). Občanský zákoník VI: závazkové právo: zvláštní část (§ 2055-3014): komentáŕr. Praha: C. H. Beck

Křeček, S. (2016). Nájemní a družstevní bydlení podle nového občanského zákoníku a zákona o obchodních korporacích. 2. aktualizované vydání. Praha: Leges

Legislation

Zákon č. 40/1964 Sb., občanský zákoník, ve znění pozdějších předpisů

Zákon č. 89/2012 Sb., občanský zákoník

Ley 29/1994, de 24 de noviembre, de Arrendamientos Urbanos

\section{Court decisions}

Rozsudek Nejvyššího soudu ze dne 18. 1. 2017, sp. zn. 26 Cdo 4249/2016.

Rozsudek Nejvyššího soudu ze dne 22. 11. 2016, sp. zn. 26 Cdo 1454/2016.

Rozsudek Nejvyššího soudu ze dne 25. 11. 2009, sp. zn. 26 Cdo 1109/2009.

Rozsudek Nejvyššího soudu ze dne 8. 4. 2009, sp. zn. 26 Cdo 1642/2008.

Rozsudek Nejvyššího soudu ze dne 20. 5. 2008, sp. zn. 26 Cdo 731/2008.

Rozsudek Nejvyššího soudu ze dne 24. 11. 2005, sp. zn. 26 Cdo 1865/2004, uveřejněný ve Sbírce soudních rozhodnutí a stanovisek pod č. 51/06.

Rozsudek Nejvyššího soudu ze dne 22. 4. 2004, sp. zn. 26 Cdo 85/2004.

Rozsudek Nejvyššího soudu ze dne 16. 3. 2004, sp. zn. 26 Cdo 1619/2003. 
Usnesení Nejvyššího soudu ze dne 6.2.2003, sp. zn. 26 Cdo 585/2002, uveřejněné pod C 1693 ve svazku 23 Souboru rozhodnutí Nejvyššího soudu.

Rozsudek Nejvyššího soudu ze dne 8. 6. 1999, sp. zn. 26 Cdo 2259/98.

Rozsudek Nejvyššího soudu ze dne 22.12. 1998, sp. zn. 2 Cdon 1246/97.

Rozsudek Nejvyššího soudu ze dne 22. 12. 1998, sp. zn. 3 Cdon 1477/96, uveřejněný v Soudní judikatuře z oblasti občanského, obchodního a pracovního práva č. 4/2000 na s. 130.

Rozsudek Nejvyššího soudu ze dne 31. 8. 1998, sp. zn. 3 Cdon 7/96, uveřejněný v Soudní judikatuře z oblasti občanského, obchodního a pracovního práva č. 21/98 na s. 492.

Rozsudek Nejvyššího soudu ze dne 26. 3. 1998, sp. zn. 3 Cdon 1/96, uveřejněný v Soudní judikatuře z oblasti občanského, obchodního a pracovního práva č. 21/98 na s. 489.

\title{
Др Лукаш Хадамчик,
}

Доцент,

Правни Факултет, Масарик Универзитет, Брно, Република Чешка

\section{НОТИФИКАЦИЈА ЗАКУПОДАВЦА О ОТКАЗУ УГОВОРА О ЗАКУПУ СТАМБЕНОГ ПРОСТОРА У ЧЕШКОМ ПРАВУ}

\begin{abstract}
Резиме
Циљ овог рада је да представи чешке прописе о престанку закупа стамбеног простора, првенствено право закуподавца на отказ уз претходну нотификацију о престанку закупа. Након општег осврта на закуп стамбеног простора у Чешкој, представљене су референтне тачке ческог грађанског законодавства у овој области. Аутор затим разматра разне категорије разлога за нотификацију о престанку закупа. Правна категоризација разлога за нотификацију о престанку закупа заснована је врсти закупа, тј. да ли је закуп договорен на неодређен или на одређен временски период. Међутим, овој категоризацији претходи посебна категорија разлога за достављање нотификације о санкцијама, који се најчешће истичу у судској пракси. Разлози који се наводе у нотификације о санкцијама обухватају нарочито озбиљну повреду обавеза од стране закупца, које је прас́ено материјалним кршењем обавеза и осудом за намерно учињено кривично дело против закуподавца или особе која живи у згради у којој се налази стан закупца, или осудом за кривично дело против имовине другог лица која се налази у згради. Аутор
\end{abstract}


затим разматра и друге разлоге за нотификацију о престанку закупа који се односе на закуп на одређено или неодређено време, попут потребе за исељењем због јавног интереса и других сличних озбиљних разлога. Смрт првобитног закупца стана је посебан разлог за достављање обавештења о престанку закупа, које се може доставити закупчевом наследнику. Узавршном делу рада аутор разматра разлоге за престанак закупа од стране закупца, који могу бити основ за достављање обавештења закуподавиу о престанку закупа али искључиво уколико је закуп договорен на неодређен временски период. У том случају, закуподавац може обавестити закупца о престанку закупа уколико у случају развода закуподавац или његов супружник намерава да живи у стану, или уколико је стан намењен за потребе становања њихових сродника или супружничких рођака.

Кључне речи: закуп стамбеног простора, нотификација о престанку закупа, чешко грађанско право, закупнина, закупац, закуподавац. 